University of South Carolina

Scholar Commons

6-11-2014

\title{
P-NEXFS Analysis of Aerosol Phosphorus Delivered to the
}

\section{Mediterranean Sea}

Amelia F. Longo

Ellery D. Ingall

Julia M. Diaz

Michelle Oakes

Laura E. King

See next page for additional authors

Follow this and additional works at: https://scholarcommons.sc.edu/geol_facpub

Part of the Earth Sciences Commons

\section{Publication Info}

Published in Volume 41, Issue 11, 2014, pages 4043-4049.

(c)2014. American Geophysical Union. All Rights Reserved.

This Article is brought to you by the Earth, Ocean and Environment, School of the at Scholar Commons. It has been accepted for inclusion in Faculty Publications by an authorized administrator of Scholar Commons. For more information, please contact digres@mailbox.sc.edu. 


\section{Author(s)}

Amelia F. Longo, Ellery D. Ingall, Julia M. Diaz, Michelle Oakes, Laura E. King, Athanasios Nenes, Nikolaos Mihalopoulos, Kaliopi Violaki, Anna Avila, Claudia R. Benitez-Nelson, Jay Brandes, Ian McNulty, and David J. Vine 


\section{Geophysical Research Letters}

\section{RESEARCH LETTER}

10.1002/2014GL060555

Key Points:

- Synchrotron-based techniques are effective tools for characterizing aerosols

- $P$ in European and North African air masses is compositionally distinct

- European aerosols deliver substantial soluble phosphorus to

the Mediterranean

Supporting Information:

- Readme

- Text S1

- Table S1

- Table S2

- Figure S1

- Figure S2

Correspondence to:

E. D. Ingall,

ingall@eas.gatech.edu

\section{Citation:}

Longo, A. F., et al. (2014), P-NEXFS analysis of aerosol phosphorus delivered to the Mediterranean Sea, Geophys. Res. Lett., 41, 4043-4049, doi:10.1002/ 2014 GL060555.

Received 16 MAY 2014 Accepted 19 MAY 2014 Accepted article online 21 MAY 2014 Published online 11 JUN 2014

\section{P-NEXFS analysis of aerosol phosphorus delivered to the Mediterranean Sea}

\author{
Amelia F. Longo ${ }^{1}$, Ellery D. Ingall ${ }^{1}$, Julia M. Diaz ${ }^{1,2}$, Michelle Oakes ${ }^{1,3}$, Laura E. King ${ }^{1}$, Athanasios Nenes ${ }^{1,4,5}$, \\ Nikolaos Mihalopoulos ${ }^{5,6}$, Kaliopi Violaki ${ }^{6}$, Anna Avila ${ }^{7}$, Claudia R. Benitez-Nelson ${ }^{8}$, Jay Brandes ${ }^{9}$, \\ Ian McNulty ${ }^{10}$, and David J. Vine ${ }^{10}$ \\ ${ }^{1}$ School of Earth and Atmospheric Sciences, Georgia Institute of Technology, Atlanta, Georgia, USA, ${ }^{2}$ Now at Biology Department, \\ Woods Hole Oceanographic Institution, Woods Hole, Massachusetts, USA, ${ }^{3}$ Now at Environmental Protection Agency, National \\ Center of Environmental Assessment, Research Triangle Park, North Carolina, USA, ${ }^{4}$ School of Chemical and Biomolecular \\ Engineering, Georgia Institute of Technology, Atlanta, Georgia, USA, ${ }^{5}$ Foundation for Research and Technology-Hellas, Patras, \\ Greece, ${ }^{6}$ Department of Chemistry, University of Crete, Heraklion, Greece, ${ }^{7}$ CREAF, Universitat Autònoma de Barcelona, \\ Bellaterra, Spain, ${ }^{8}$ Department of Earth and Ocean Sciences and Marine Science Program, School of the Earth, Ocean \& \\ Environment, College of Arts and Sciences, University of South Carolina, Columbia, South Carolina, USA, ${ }^{9}$ Skidaway Institute of \\ Oceanography, Savannah, Georgia, USA, ${ }^{10}$ Advanced Photon Source, Argonne National Laboratory, Argonne, Illinois, USA
}

Abstract Biological productivity in many ocean regions is controlled by the availability of the nutrient phosphorus. In the Mediterranean Sea, aerosol deposition is a key source of phosphorus and understanding its composition is critical for determining its potential bioavailability. Aerosol phosphorus was investigated in European and North African air masses using phosphorus near-edge X-ray fluorescence spectroscopy (P-NEXFS). These air masses are the main source of aerosol deposition to the Mediterranean Sea. We show that European aerosols are a significant source of soluble phosphorus to the Mediterranean Sea. European aerosols deliver on average 3.5 times more soluble phosphorus than North African aerosols and furthermore are dominated by organic phosphorus compounds. The ultimate source of organic phosphorus does not stem from common primary emission sources. Rather, phosphorus associated with bacteria best explains the presence of organic phosphorus in Mediterranean aerosols.

\section{Introduction}

Atmospheric deposition is an important source of nutrients to oligotrophic ocean regions [Graham and Duce, 1982; Mahowald et al., 2008]. In the eastern Mediterranean Sea, biological productivity is strongly limited by the vital nutrient phosphorus [Krom et al., 1991, 2010], with aerosol deposition accounting for at least one third of all phosphorus inputs [Ganor and Mamane, 1982]. Large dust plumes, clearly visible in satellite images, stretch from North Africa to the Mediterranean Sea. Perhaps as a consequence of this visible and obviously significant contribution, previous studies have mainly focused on northern Africa as the major source of nutrients to the Mediterranean [Escudero et al., 2011; Ganor and Mamane, 1982; Guerzoni et al., 1999]. Despite the eastern Mediterranean basin receiving air masses from Europe at least $70 \%$ of the time [Kouvarakis et al., 2001], phosphorus within European-sourced aerosols has not been as extensively studied due to comparatively lower mass deposition. Yet it is the composition of the aerosol and the ability of microorganisms to assimilate nutrients from this source, i.e., bioavailability that must also be considered.

Phosphorus bioavailability has traditionally been linked to the composition and abundance of different chemical phases [Beauchemin et al., 2003; Mackey et al., 2012]. Phosphorus is thought to be bioavailable when present as highly soluble inorganic and organic compounds. Assessments of phosphorus bioavailability in aerosols have been challenged by current analytical limitations. Typically, studies of aerosol phosphorus rely upon sequential chemical extraction or leaching techniques to assess the composition and therefore the potential bioavailability of phosphorus [Anderson et al., 2010; Chen et al., 2006; Izquierdo et al., 2012; Markaki et al., 2003; Ridame and Guieu, 2002]. These techniques have painted a complex picture of aerosol phosphorus composition, showing that phosphorus occurs in a number of different phases including organic, inorganic, and mineral forms and that these phases can undergo many transformations in response to environmental conditions [Anderson et al., 2010; Baker et al., 2006; Chen et al., 2006; Nenes et al., 2011]; however, phases used to calibrate extraction methods were developed for soil and marine sediment analysis, 
thus may not be entirely representative of phosphorus phases found in aerosol. Here we combine novel synchrotron-based techniques with traditional analyses to show that European aerosols contribute phosphorus to the Mediterranean Sea, which is vastly different in phosphorus composition and solubility than North African aerosols.

\section{Methods}

\subsection{Ambient Aerosol Collection}

Air masses originating in North Africa and Europe were sampled at the Finokalia research station $\left(35^{\circ} 32^{\prime} \mathrm{N}, 25^{\circ} 67^{\prime} \mathrm{E}\right)$, a remote site on the island of Crete, Greece, located $70 \mathrm{~km}$ from the nearest major city. This site was chosen as it is isolated from both local and regional influences [Markaki et al., 2003], making it an ideal location for examining the transport of long range aerosols. Samples of particulate matter with an aerodynamic diameter $<10 \mu \mathrm{m}, \mathrm{PM10}$, were collected on Teflon filters using a virtual impactor with an operational flow rate of $16.7 \mathrm{~L} \mathrm{~min}^{-1}$. Samples were collected over a 1 to 3 day period from 2009 to 2011 during which either North African or European air masses dominated (Table S1 in the supporting information). A total of 14 samples was analyzed, five from European and nine from North African air masses (Table S1), hereafter referred to as simply European and North African samples. Hybrid Single Particle Lagrangian Integrated Trajectory Model (HYSPLIT) [Draxier and Hess, 1998; Izquierdo et al., 2012] back trajectories were completed for each sample in order to confirm the geographic origin of the air masses sampled. HYSPLIT back trajectories were calculated between $1000 \mathrm{~m}$ and $3000 \mathrm{~m}$ above ground level for 5 days preceding sample collection (Figure S1). HYSPLIT back trajectories were computed at $3000 \mathrm{~m}$ to confirm dust events. Dust is either homogeneously distributed from 0 to about $3000 \mathrm{~m}$, during spring and autumn dust events, or is found in a layer between 2500 and $4000 \mathrm{~m}$ during summer and autumn dust events [Kalivitis et al., 2007]. HYSPLIT back trajectories computed at $1000 \mathrm{~m}$ show the origin of air masses within the boundary layer; this height is chosen, rather than the more conventional heights of $0 \mathrm{~m}$ or $500 \mathrm{~m}$, to avoid orographic problems. While HYSPLIT back trajectories do not guarantee that pure end-members were sampled, the air masses were dominated by either North African or European origins. Ambient aerosol samples were stored at $-20^{\circ} \mathrm{C}$ until analysis.

\subsection{Emission Source Collection}

Emissions from ultralow sulfur diesel fuel and gasoline were collected using U.S. Environmental Protection Agency protocols under typical urban driving conditions [Oakes et al., 2012b]. Coal fly ash from an electrostatic precipitator, provided by The Southern Company, was aerosolized and collected with a PM2.5 cyclone inlet sampler [Oakes et al., 2012b]. Smoke produced from the burning of materials collected from coniferous and deciduous trees native to Georgia, USA, was sampled during a controlled biomass burning experiment using a cyclone inlet sampler placed $3.5 \mathrm{~m}$ above the burn area at a flow rate of $16.7 \mathrm{~L} \mathrm{~min}^{-1}$ for approximately $30 \mathrm{~min}$. The ash produced from the biomass burning experiment was also analyzed. Although emission sources were not collected from European or North African locations, source materials presented here are considered to be reasonably similar to those found in Europe and North Africa. Thus, these emission source end-members are used as a proxy for primary phosphorus sources found in European and North African air masses. In addition, the following commercially available source materials were analyzed: pollen (Quercus ruba; Sigma P7895), the bacteria Azotobacter vinelandii (Sigma A2135), and the bacteria Bacillus subtilis (Sigma B4006). These commercially available materials were handled and analyzed in the same manner as the phosphorus standards (supporting information). Emission source samples were stored at $-20^{\circ} \mathrm{C}$ until analysis.

\subsection{Total Phosphorus and Soluble Phosphate Determination}

Total phosphorus was measured for all samples with a technique employing high-temperature combustion $\left(550^{\circ} \mathrm{C}\right.$ for $2 \mathrm{~h}$ ) followed by extraction in acid ( $1 \mathrm{~N} \mathrm{HCl}$, agitated for $24 \mathrm{~h}$ ) [Aspila et al., 1976]. The extracts were centrifuged prior to analysis to remove suspended particles. Total phosphorus content was measured using standard spectrophotometric techniques [Murphy and Riley, 1962]. Soluble phosphate was determined for all samples collected at the Finokalia research station. For these samples, half of a Teflon filter was extracted by sonicating with $15 \mathrm{~mL}$ of nanopure water (Milli-Q, resistivity: $18.2 \mathrm{M} \Omega \mathrm{cm}$ ) for $45 \mathrm{~min}$. It should be noted that sonication could extract organic phosphorus; therefore, this method can overestimate soluble phosphate in a sample. Prior to analysis, each extracted solution was filtered through polyethersulfone membrane filters $(0.45 \mu \mathrm{m}$ pore size diameter), to remove suspended particles. A Dionex AS4A-SC column with ASRS-ULTRA-II suppressor 
in autosuppression mode of operation was used for the analysis of dissolved inorganic phosphate (DIP). The reproducibility of the measurements defined as standard deviation of five consecutive analyses was better than $2 \%$. The detection limit, defined as 3 times the standard deviation of the blank, was $0.06 \mu \mathrm{M}$ DIP.

\subsection{Synchrotron-Based X-ray Spectromicroscopy}

Samples were analyzed on the X-ray fluorescence microscope located at beamline 2-ID-B at the Advanced Photon Source, Argonne National Laboratory. The beamline is optimized to examine samples over a 1-4 keV energy range using a focused X-ray beam with a spot size of approximately $100 \mathrm{~nm}^{2}$ [McNulty et al., 2003]. Phosphorus near-edge X-ray fluorescence spectroscopy (P-NEXFS) data were collected in two modes that differ based on spatial resolution. In the first mode, individual phosphorus-rich particles with a diameter of greater than $1 \mu \mathrm{m}$ were identified in X-ray fluorescence maps; these particles were then interrogated with micro P-NEXFS. The individual phosphorus-rich particles seen in X-ray fluorescence maps are obvious contributors to total sample phosphorus. However, much of the total phosphorus on an aerosol filter can also be contained in particles that are less phosphorus-rich and therefore less apparent in X-ray fluorescence maps. Therefore, in the second mode, large areas of the filters were also examined with an unfocused beam (spot size $=0.28 \mathrm{~mm}^{2}$ ) to obtain bulk spectra representative of the average phosphorus phase present.

In order to maximize the number of samples analyzed in the allotted time, $\mathrm{X}$-ray fluorescence maps were created by rastering the focused beam in $0.5 \mu \mathrm{m}$ steps with an incident energy of $2185 \mathrm{eV}$. At this resolution, individual phosphorus-rich particles were clearly discernible. P-NEXFS spectra were collected over an energy range of 2130 to $2210 \mathrm{eV}$ in $0.33 \mathrm{eV}$ steps, using a $1 \mathrm{~s}$ dwell time at each step. Each P-NEXFS measurements for both bulk and individual phosphorus-rich particles were repeated at least 3 times, in a single position, creating a minimum effective dwell time of $3 \mathrm{~s}$. X-ray spectromicroscopy data were collected using an energy dispersive silicon drift detector (Ketek with a $5 \mathrm{~mm}^{2}$ sensitive area). A flow of helium was introduced between the X-ray optical hardware and the sample to reduce X-ray backscatter. An in-line monitor stick composed of fluorapatite was measured with each sample in order to identify and correct for any potential drift in monochrometer energy calibration that occurred during analyses [de Jonge et al., 2010]. Clean areas of Teflon and cellulose acetate filters were examined as blanks and showed negligible background signal.

P-NEXFS provides essentially the same information as another commonly cited technique, P-XANES (phosphorus X-ray absorption near-edge structure) spectroscopy. The two techniques differ primarily in the method of signal detection. P-NEXFS uses the X-ray fluorescence signal which is inversely proportional to the absorption signal used in a XANES measurement.

\subsection{P-NEXFS Data Analysis}

Linear combination fitting is an effective tool for the deconvolution of spectra of known mixtures [Ajiboye et al., 2007]. Using Athena software [Ravel and Newville, 2005], individual particle and bulk P-NEXFS spectra were fit with previously characterized phosphorus standard materials using a linear combination approach to determine both speciation and relative abundance of phosphorus phases [Prietzel et al., 2013]. Additionally, bulk P-NEXFS spectra of ambient aerosol were fit using emission sources rather than standards; this approach was used to determine if phosphorus in ambient aerosols could be accounted for solely by emission sources. Athena uses a nonlinear, least squares minimization approach to fit spectra of unknown materials with spectra of standard materials and computes an error term, $R$ factor, to quantify the goodness of fit produced by a particular linear combination of standard P-NEXFS spectra. The linear combination of standards that yielded the lowest $R$ factor reflects the best fit [Ravel and Newville, 2005].

The data for an individual P-NEXFS spectrum were normalized to create a relative intensity value of approximately 1 for post-edge area of the spectra $(>2160 \mathrm{eV})$. The data were also processed using a threepoint smoothing algorithm built into the software. Smoothing did not appreciably change the data, other than removing high-frequency noise. The standard database used in our spectral linear combination fitting included phosphorus minerals and inorganic phosphorus compounds discussed in Ingall et al. [2011], as well as a variety of organic phosphorus compounds (supporting information). An iterative process was used to refine the standard database used to model the sample spectra. First, complex, high-temperature, and highpressure minerals, unlikely to be major components of aerosol phosphorus, were excluded from the database [Oakes et al., 2012a]. Second, the database was narrowed through elimination of standards with low contribution (i.e., less than $10 \%$ ) or poor fit (i.e., high $R$ factor) during initial linear combination fitting. 


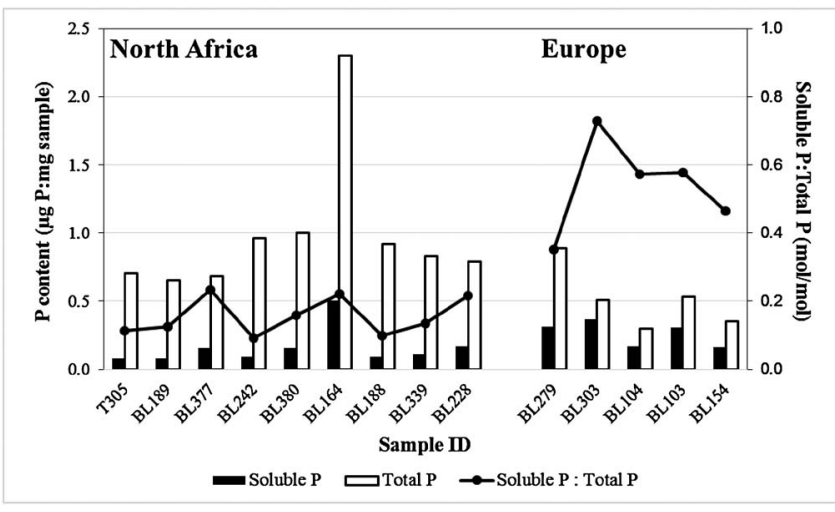

Figure 1. The soluble and total phosphorus contained in Mediterranean aerosols are shown for air masses originating in Europe and North Africa. Total phosphorus content (white) and soluble phosphorus content (black) show that both European and North African samples are potential sources of phosphorus to the Mediterranean Sea. The molar ratio of soluble phosphorus to total phosphorus (line) expressed as a percentage shows that European aerosol can be up to 4.7 times more soluble than North African aerosol. Typically, the reproducibility for measuring soluble phosphorus and total phosphorus is $2 \%$ and $10 \%$, respectively.
Finally, the composition of individual phosphorus-rich particles determined using micro P-NEXFS helped to guide the choice of standards for the modeling of bulk P-NEXFS spectra.

Spectra can be very similar within certain compound classes like phosphorus esters (Figure S2) and mineral classes like apatites [Ingall et al., 2011]. Also, insufficient quantities of a specific mineral or compound in a sample can also lead to underestimation of the specific compound during linear combination fitting [Hesterberg, 2010]. We therefore generalized our results into four chemical classes, apatite, metal phosphates, alkali and alkaline earth metal phosphates, and organic phosphorus + polyphosphate, with distinct implications for phosphorus solubility and bioavailability. The apatite chemical class includes fluorapatite, hydroxyapatite, carbonate fluorapatite and carbonate hydroxyapatite, and chlorapatite. Minerals in the metal phosphate chemical class have a dominant metal cation like iron, copper, or manganese and include vauxite, cornetite, wardite, and wolfeite. Alkali and alkaline earth metal phosphates (hereafter referred to as alkali phosphates) include sodium phosphate and calcium dihydrogen phosphate; these phases typically have high solubility. The final chemical class, organic phosphorus + polyphosphate, includes organic compounds like adenosine-5'-triphosphate (ATP), lipids (and other phosphorus esters), and polyphosphates, all compounds of biological origin.

\section{Results and Discussion}

\subsection{Ambient Aerosols}

Aerosol phosphorus from North African air masses was on average $15.5 \pm 14.1 \%$ soluble. In contrast, aerosol phosphorus from European air masses was on average $54.0 \pm 5.6 \%$ soluble (Figure 1). Despite Europeansourced aerosols having less total phosphorus than North African aerosols, the mass of soluble phosphorus

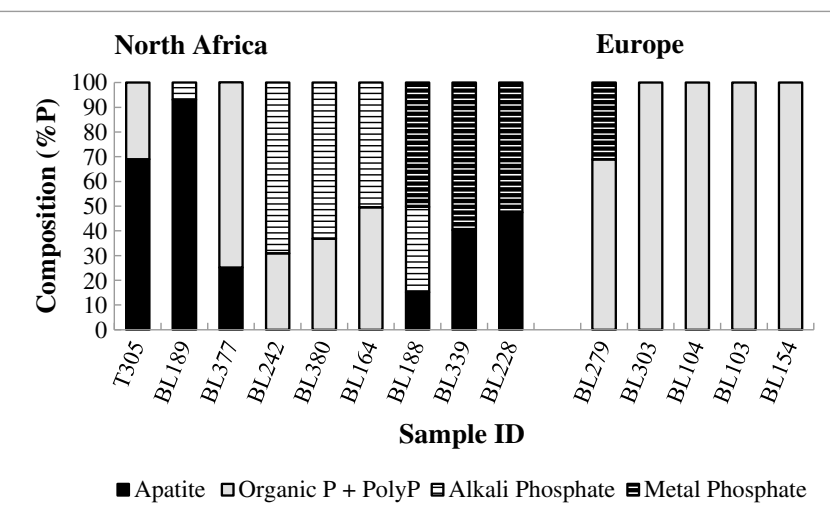

Figure 2. Linear combination fitting of each aerosol spectra was used to determine the phosphorus composition in each sample. The distribution of apatite (black), organic phosphorus + polyphosphate (grey), alkali phosphates (white striped), and metal phosphates (black striped) determined through linear combination fitting is shown for each sample. per mass of aerosol is comparable

(Figure 1). Consistent with our findings based on our limited sample set, sequential extraction methods have shown that anthropogenically influenced air masses, such as those originating in Europe, tend to have more soluble phosphorus than North African aerosol [Anderson et al., 2010; Izquierdo et al., 2012]. Our bulk P-NEXFS measurements further showed that European-sourced aerosols were dominated by the organic phosphorus + polyphosphate chemical class and were on average composed of $93.8 \pm 13.9 \%$ organic phosphorus + polyphosphate and $6.2 \pm 13.9 \%$ metal phosphate, with no alkali phosphates or apatite (Figure 2). In contrast, the average phosphorus 

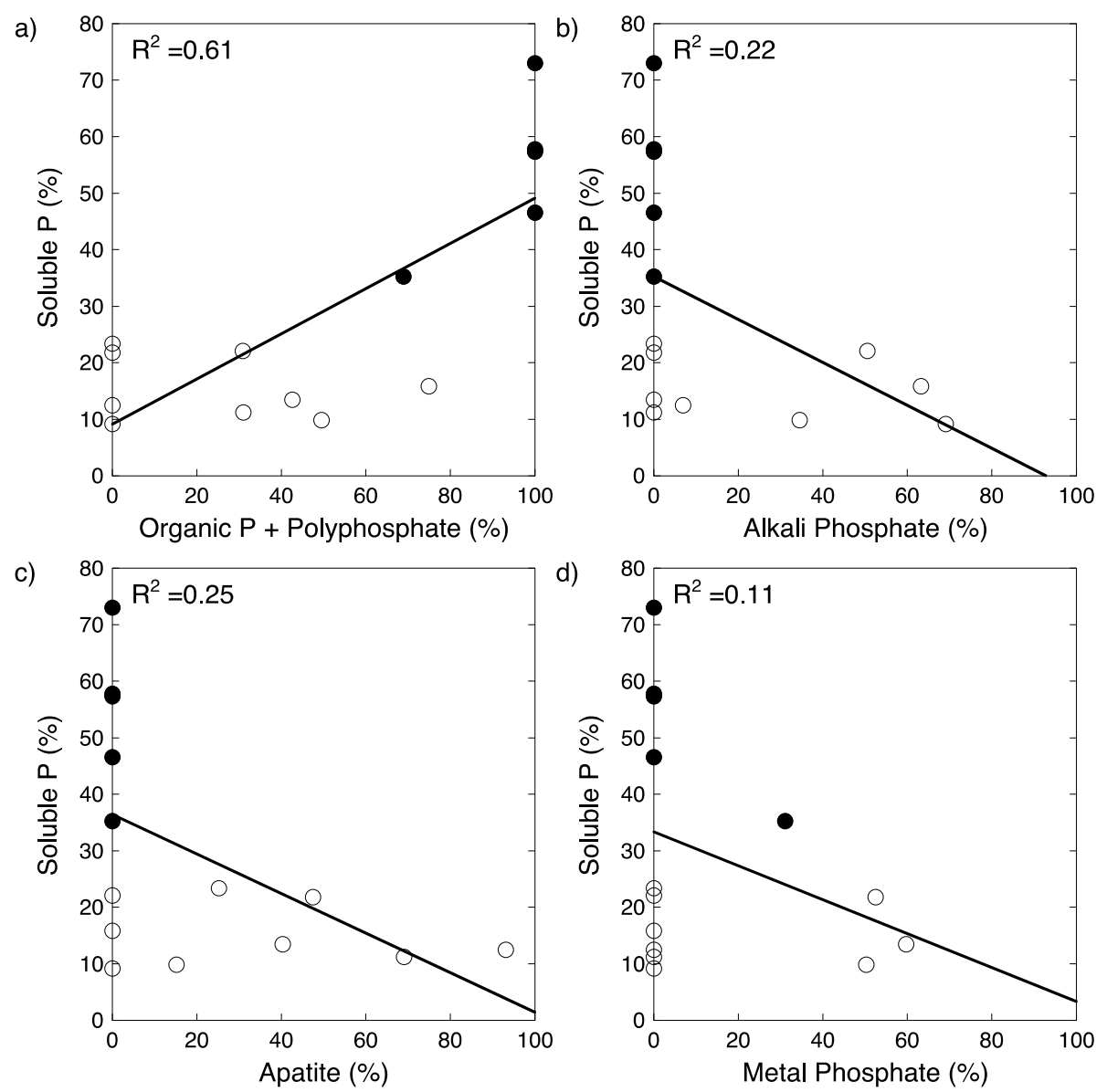

Figure 3. Plots of percent soluble phosphorus versus phosphorus composition are shown for North African- (open circles) and European- (solid circles) sourced aerosol samples. The only chemical class showing a notable correlation with solubility is organic phosphorus + polyphosphate suggesting that this class does in part influence solubility.

composition of North African-sourced aerosols was $32.3 \pm 33.2 \%$ apatite, $24.9 \pm 29.5 \%$ alkali phosphates, $24.8 \pm 26.9 \%$ organic phosphorus + polyphosphate, and $18.1 \pm 27.2 \%$ metal phosphate (Figure 2). Micro P-NEXFS analysis revealed that individual phosphorus-rich particles from European and North African air masses were often solely composed of organic phosphorus + polyphosphate or apatite, respectively.

Previous studies based on sequential extraction techniques have shown that apatite is the most abundant phosphorus phase followed by oxide-associated phosphorus in North African-sourced air masses [Anderson et al., 2010; Nenes et al., 2011]. Our results suggest organic phosphorus + polyphosphate as well as alkali phosphates accounts for a large fraction of the phosphorus in the North African-derived aerosol (Figure 2). The oxide-associated phosphorus fraction determined by sequential extraction techniques can include labile organic phosphorus as well [Anderson et al., 2010]. Therefore, our finding of organic phosphorus + polyphosphate in North African-sourced aerosols could be consistent with chemical extraction methods and suggests that organic phosphorus is present in the oxide-associated fraction identified in these studies. The presence of alkali phosphates in North African air masses may reflect recycling of apatite-derived phosphorus. At low $\mathrm{pH}$, apatite more readily dissolves into aerosol water droplets [Anderson et al., 2010] that are subsequently dehydrated, possibly resulting in supersaturation of these droplets with respect to alkali phosphates. If sulfuric acid is the dominant acidic species present, aerosol water content may continue to be high even at low $\mathrm{pH}$, which further facilitates dissolution of phosphorus.

Soluble phosphorus percentage shows the strongest correlation with the relative abundance of organic phosphorus + polyphosphate (Figure 3). However, the correlation coefficient of 0.61 indicates that significant variability in this relationship exists, likely tied to the abundance and solubility of specific organic phosphorus 
compounds within the defined chemical class. Organic phosphorus compounds exhibit a wide range of structures and compositions that are generally not possible to distinguish with P-NEXFS (supporting information). These species, in turn, differ in terms of phosphorus solubility. Also, acidification of normally insoluble phosphorus phases can increase phosphorus solubility [Nenes et al., 2011]. Anthropogenic emissions are well-documented sources of acidic species [Nenes et al., 2011] and have also been linked to more soluble forms of aerosol phosphorus [Izquierdo et al., 2012; Zamora et al., 2013]. Varying quantities of acidic species [Nenes et al., 2011] entrained in European and North African air masses would likely lead to different levels of phosphorus solubilization during atmospheric transport.

\subsection{Emission Sources}

In addition to ambient aerosol samples, several common emission sources were analyzed with bulk P-NEXFS. Spectral linear combination fitting showed that pollen and the bacteria Bacillus subtillis and Azotobacter vinelandii were dominated by organic phosphorus + polyphosphate. Coal fly ash, diesel, volcanic ash, and biomass burning ash were composed of apatite, metal phosphates, and organic phosphorus + polyphosphate. Neither gasoline nor biomass burning emissions showed a discernable phosphorus edge, so phosphorus composition could not be characterized for these sources. Spectral linear combination fits based only on source emission spectra for ambient aerosol samples were usually inferior to fits utilizing phosphorus compounds and minerals. The dissimilarity between source emissions and ambient aerosol suggests either that atmospheric processing strongly modifies phosphorus composition or that another unknown phosphorus source is a dominant aerosol component. For example, aerosol production by plants and other organisms is a possible source of organic aerosol phosphorus [Artaxo et al., 2002; Benitez-Nelson, 2000]. Biogenic pathways involved in aerosol production remain uncertain [Artaxo et al., 2002; Benitez-Nelson, 2000]; however, primary emissions from vegetative cover could also account for the dominance of organic phosphorus + polyphosphate class seen in European air masses. Microbial cells have also been recognized as an important natural component of aerosol [Bauer et al., 2002; Burrows et al., 2009]. Due to a globally ubiquitous distribution [Bauer et al., 2002; Burrows et al., 2009], bacteria are potentially a key contributor to the organic fractions present in both the North African and European aerosols examined here. In fact, when various emission sources were used as standards in spectral linear combination fitting, fits containing bacteria as a standard produced the best results for ambient aerosols sampled from both North African and European air masses.

Acknowledgments

This material is based upon work supported by the National Science

Foundation under grants OCE 1060884 and OCE 1357375, and the data used to produce these results are available upon request to the corresponding author.

Any opinions, findings, and conclusions or recommendations expressed in this material are those of the authors and do not necessarily reflect the views of the National Science Foundation. Use of the Advanced Photon Source is supported by the U.S. Department of Energy, Office of Basic Energy Sciences under contract DE-AC02-06CH11357. N.M. and K.V. acknowledge support from European Union (European Social Fund) and Greek national funds through the Operational Program "Education and Lifelong Learning" of the National Strategic Reference Framework Research Funding Program, ARISTEIA. We thank John Jansen at Southern Co. and Bill Preston at the EPA for providing source emission samples. Finally, we thank Terry Lathem for the volcanic ash sample.

The Editor thanks two anonymous reviewers for their assistance in evaluating this paper.

\section{Conclusions}

This work demonstrates, based on our limited data set, that synchrotron-based techniques provide valuable insights into the composition and therefore the factors influencing the solubility and bioavailability of phosphorus in aerosols. The distinctively higher phosphorus solubility in European aerosol is attributed largely to the presence of organic phosphorus. Preliminary evidence suggests that this organic phosphorus may be associated with bacteria; however, further research is necessary to specifically characterize the organic phosphorus-containing phases and determine the prevalence of bacteria in Mediterranean aerosols. Shifts in wind direction observed over seasonal and interannual time scales [Chamard et al., 2003] have been suggested as a key factor controlling the delivery of vital nutrients to marine systems [Hamza et al., 2011]. Climate simulations suggest that European-sourced winds will be more prevalent over the Mediterranean Sea than North African-sourced winds in the future [McInnes et al., 2011]. If phosphorus in European aerosols is consistently shown to be 3.5 times more soluble than North African aerosol, then predicted increases in European influences will lead to more soluble phosphorus loading to the Mediterranean Sea and ultimately more biological productivity.

\section{References}

Ajiboye, B., O. O. Akinremi, and A. Jurgensen (2007), Experimental validation of quantitative XANES analysis for phosphorus speciation, Soil Sci. Soc. Am. J., 71(4), 1288-1291.

Anderson, L. D., K. L. Faul, and A. Paytan (2010), Phosphorus associations in aerosols: What can they tell us about P bioavailability?, Mar. Chem., $120(1-4), 44-56$

Artaxo, P., J. V. Martins, M. A. Yamasoe, A. S. Procopio, T. M. Pauliquevis, M. O. Andreae, P. Guyon, L. V. Gatti, and A. M. C. Leal (2002), Physical and chemical properties of aerosols in the wet and dry seasons in Rondonia, Amazonia, J. Geophys. Res., 107(D20), 8081, doi:10.1029/2001JD000666.

Aspila, K. I., H. Agemian, and A. S. Y. Chau (1976), A semi-automated method for the determination of inorganic, organic and total phosphate in sediments, Analyst, 101, 187-197. 
Baker, A. R., T. D. Jickells, M. Witt, and K. L. Linge (2006), Trends in the solubility of iron, aluminium, manganese and phosphorus in aerosol collected over the Atlantic Ocean, Mar. Chem., 98(1), 43-58.

Bauer, H., A. Kasper-Giebl, M. Loflund, H. Giebl, R. Hitzenberger, F. Zibuschka, and H. Puxbaum (2002), The contribution of bacteria and fungal spores to the organic carbon content of cloud water, precipitation and aerosols, Atmos. Res., 64(1-4), $109-119$.

Beauchemin, S., D. Hesterberg, J. Chou, M. Beauchemin, R. R. Simard, and D. E. Sayers (2003), Speciation of phosphorus in phosphorus-enriched agricultural soils using X-ray absorption near-edge structure spectroscopy and chemical fractionation, J. Environ. Qual., 32(5), 1809-1819.

Benitez-Nelson, C. R. (2000), The biogeochemical cycling of phosphorus in marine systems, Earth Sci. Rev., 51(1-4), 109-135.

Burrows, S. M., W. Elbert, M. G. Lawrence, and U. Poschl (2009), Bacteria in the global atmosphere—Part 1: Review and synthesis of literature data for different ecosystems, Atmos. Chem. Phys., 9(23), 9263-9280.

Chamard, P., F. Thiery, A. Di Sarra, L. Ciattaglia, L. De Silvestri, P. Grigioni, F. Monteleone, and S. Piacentino (2003), Interannual variability of atmospheric $\mathrm{CO}(2)$ in the Mediterranean: Measurements at the island of Lampedusa, Tellus, Ser. B, 55(2), 83-93.

Chen, H. Y., T. H. Fang, M. R. Preston, and S. Lin (2006), Characterization of phosphorus in the aerosol of a coastal atmosphere: Using a sequential extraction method, Atmos. Environ., 40(2), 279-289.

de Jonge, M. D., D. Paterson, I. McNulty, C. Rau, J. A. Brandes, and E. Ingall (2010), An energy and intensity monitor for X-ray absorption near-edge structure measurements, Nucl. Instrum. Methods Phys. Res., Sect. A, 619(1-3), 154-156.

Draxier, R. R., and G. D. Hess (1998), An overview of the HYSPLIT_4 modelling system for trajectories, dispersion and deposition, Aust. Meteorol. Mag., 47(4), 295-308.

Escudero, M., A. F. Stein, R. R. Draxler, X. Querol, A. Alastuey, S. Castillo, and A. Avila (2011), Source apportionment for African dust outbreaks over the Western Mediterranean using the HYSPLIT model, Atmos. Res., 99(3-4), 518-527.

Ganor, E., and Y. Mamane (1982), Transport of Saharan dust across the eastern Mediterranean, Atmos. Environ., 16(3), $581-587$.

Graham, W. F., and R. A. Duce (1982), The atmospheric transport of phosphorus to the western North-Atlantic, Atmos. Environ., 16(5), 1089-1097.

Guerzoni, S., et al. (1999), The role of atmospheric deposition in the biogeochemistry of the Mediterranean Sea, Prog. Oceanogr., 44(1-3), 147-190.

Hamza, W., M. R. Enan, H. Al-Hassini, J. B. Stuut, and D. de-Beer (2011), Dust storms over the Arabian Gulf: A possible indicator of climate changes consequences, Aquat. Ecosyst. Health Manage., 14(3), 260-268.

Hesterberg, D. (2010), Macroscale chemical properties and X-ray absorption spectroscopy of soil phosphorus, in Developments in Soil Science, chap. 11, pp. 313-356, Elsevier, Amsterdam, Netherlands.

Ingall, E., J. Brandes, J. Diaz, M. de Jonge, D. Paterson, I. McNulty, W. Elliott, and P. Northrup (2011), Phosphorus K-edge XANES spectroscopy of mineral standards, J. Synchrotron Radiat., 18, 189-197.

Izquierdo, R., C. R. Benitez-Nelson, P. Masque, S. Castillo, A. Alastuey, and A. Avila (2012), Atmospheric phosphorus deposition in a near-coastal rural site in the NE Iberian Peninsula and its role in marine productivity, Atmos. Environ., 49, 361-370.

Kalivitis, N., E. Gerasopoulos, M. Vrekoussis, G. Kouvarakis, N. Kubilay, N. Hatzianastassiou, I. Vardavas, and N. Mihalopoulos (2007), Dust transport over the eastern Mediterranean derived from Total Ozone Mapping Spectrometer, Aerosol Robotic Network, and surface measurements, J. Geophys. Res., 112, D03202, doi:10.1029/2006JD007510.

Kouvarakis, G., N. Mihalopoulos, A. Tselepides, and S. Stavrakaki (2001), On the importance of atmospheric inputs of inorganic nitrogen species on the productivity of the eastern Mediterranean Sea, Global Biogeochem. Cycles, 15(4), 805-817, doi:10.1029/2001GB001399.

Krom, M. D., N. Kress, S. Brenner, and L. I. Gordon (1991), Phosphorus limitation of primary productivity in the eastern Mediterranean Sea, Limnol. Oceanogr., 36(3), 424-432.

Krom, M. D., K. C. Emeis, and P. Van Cappellen (2010), Why is the eastern Mediterranean phosphorus limited?, Prog. Oceanogr., 85(3-4), 236-244.

Mackey, K. R. M., K. Roberts, M. W. Lomas, M. A. Saito, A. F. Post, and A. Paytan (2012), Enhanced solubility and ecological impact of atmospheric phosphorus deposition upon extended seawater exposure, Environ. Sci. Technol., 46(19), 10,438-10,446.

Mahowald, N., et al. (2008), Global distribution of atmospheric phosphorus sources, concentrations and deposition rates, and anthropogenic impacts, Global Biogeochem. Cycles, 22, GB4026, doi:10.1029/2008GB003240.

Markaki, Z., K. Oikonomou, M. Kocak, G. Kouvarakis, A. Chaniotaki, N. Kubilay, and N. Mihalopoulos (2003), Atmospheric deposition of inorganic phosphorus in the Levantine Basin, eastern Mediterranean: Spatial and temporal variability and its role in seawater productivity, Limnol. Oceanogr., 48(4), 1557-1568

Mclnnes, K. L., T. A. Erwin, and J. M. Bathols (2011), Global Climate Model projected changes in $10 \mathrm{~m}$ wind speed and direction due to anthropogenic climate change, Atmos. Sci. Lett., 12(4), 325-333.

McNulty, I., et al. (2003), The 2-ID-B intermediate-energy scanning X-ray microscope at the APS, J. Phys. IV, 104, 11-15.

Murphy, J., and J. P. Riley (1962), A modified single solution method for the determination of phosphate in natural waters, Anal. Chim. Acta, $27,31-36$.

Nenes, A., M. D. Krom, N. Mihalopoulos, P. Van Cappellen, Z. Shi, A. Bougiatioti, P. Zarmpas, and B. Herut (2011), Atmospheric acidification of mineral aerosols: A source of bioavailable phosphorus for the oceans, Atmos. Chem. Phys., 11(13), 6265-6272.

Oakes, M., R. J. Weber, B. Lai, A. Russell, and E. D. Ingall (2012a), Characterization of iron speciation in urban and rural single particles using XANES spectroscopy and micro X-ray fluorescence measurements: Investigating the relationship between speciation and fractional iron solubility, Atmos. Chem. Phys., 12(2), 745-756.

Oakes, M., E. D. Ingall, B. Lai, M. M. Shafer, M. D. Hays, Z. G. Liu, A. G. Russell, and R. J. Weber (2012b), Iron solubility related to particle sulfur content in source emission and ambient fine particles, Environ. Sci. Technol., 46(12), 6637-6644.

Prietzel, J., A. Dümig, Y. Wu, J. Zhou, and W. Klysubun (2013), Synchrotron-based P K-edge XANES spectroscopy reveals rapid changes of phosphorus speciation in the topsoil of two glacier foreland chronosequences, Geochim. Cosmochim. Acta, 108, $154-171$.

Ravel, B., and M. Newville (2005), ATHENA, ARTEMIS, HEPHAESTUS: Data analysis for X-ray absorption spectroscopy using IFEFFIT, J. Synchrotron Radiat., 12, 537-541.

Ridame, C., and C. Guieu (2002), Saharan input of phosphate to the oligotrophic water of the open western Mediterranean Sea, Limnol. Oceanogr., 47(3), 856-869.

Zamora, L. M., J. M. Prospero, D. A. Hansell, and J. M. Trapp (2013), Atmospheric P deposition to the subtropical North Atlantic: Sources, properties, and relationship to N deposition, J. Geophys. Res. Atmos., 118, 1546-1562, doi:10.1002/jgrd.50187. 